\title{
МИНЕРАЛОГИЯ ЗОЛОТА, СЕРЕБРА, ПЛАТИНЫ И ПАЛЛАДИЯ В ЗАЛЕЖАХ БЕЛОГОРСКОГО ЖЕЛЕЗОРУДНОГО МЕСТОРОЖДЕНИЯ (ПРИМОРЬЕ)
}

\author{
Е. В. Перевозникова, В. Т. Казаченко \\ Дальневосточный геологический институт ДВО РАН, г. Владивосток
}

Поступила в редакцию 2 апреля 2019 г.

\begin{abstract}
Аннотация: в статье приведены результаты изучения золото-серебро-палладий платиновой минерализации в залежах Белогорского железорудного месторождения (Приморье). Она представлена неупорядоченными твердыми растворами золота и серебра, золота и меди переменного состава, а также интерметаллическими соединениями, близкими по составу к купроауриду и аурикуприду, самородной платиной без примесей, медьсодержащей платиной, соединениями платинь с палладием и платины с серебром и другими минералами. Благороднометальная минерализаџия 8 скарновых залежах Белогорского месторождения имеет двойственную природу. Она образовалась в проиессе метаморфизма за счет вещчества протолитов (накапливавшихся в лагунах островов продуктов размыва латеритной коры выветривания габброидов), а также за счет благородных металлов триасовых углеродистых силищитов, мигрировавших по трещчнам в другие породы в составе флюида с высоко- и ультравосстановительными способностями. Обогащение благородными и другими металлами протолитов скарнов, триасовых металлоносных осадков (накапливавшихся в прилегавших к островам акваториях) и триасовых углеродистых силицитов обусловлено, вероятно, их сорбированием гидроксидами Мn и Fе и органическим веществом в прочессе экзогенного выветривания слагавших острова древних габброидов Сихотэ-Алиня.
\end{abstract}

Ключевые слова: магнетитовое месторождение, золото, серебро, платина, палладий, минералогия, Сихотэ-Алинь.

\section{MINERALOGY OF GOLD, SILVER, PLATINUM AND PALLADIUM OF THE BELOGORSKY IRON ORE DEPOSIT (PRIMORYE)}

\begin{abstract}
: this article presents the results of the study of gold-silver-palladium-platinum mineralization of the Belogorsky iron ore deposit (Primorye). It is represented by disordered solid solutions of gold and silver, gold and copper of variable composition, intermetallic compounds similar in composition to cuproauride and auricupride, native platinum without impurities, copper-containing platinum, compounds of platinum with palladium and platinum with silver and other minerals. Noble-metal mineralization in the skarn deposits of the Belogorsky deposit has a dual nature. It was formed in the process of metamorphism due to the substance of the protoliths (accumulated in the lagoons of the Islands of the products of erosion of the lateritic weathering crust of gabbroids), and also due to the noble metals in Triassic carbonaceous silicites, migrated through cracks in other rocks in the fluid composition with high and ultraregenerative abilities. Enrichment of the skarn protoliths, Triassic metal-bearing sediments (accumulated in the waters adjacent to the Islands) and Triassic carbon silicites of noble and other metals must have been caused by their sorption with Mn and Fe hydroxides and organic matter in the process of exogenous weathering of the ancient gabbroids composing the Islands of the Sikhote-Alin.
\end{abstract}

Keywords: magnetite deposit, gold, silver, platinum, palladium, mineralogy, the Sikhote-Alin.

\section{Введение}

Относимые к скарнам известково-силикатные породы месторождений с железными, полиметаллическими и боросиликатными рудами Ольгинского и Дальнегорского рудных районов Сихотэ-Алиня изначально являлись продуктами размыва латеритной коры выветривания (поздний анизий-конец триаса) древних габброидов, накапливавшимися в лагунах островов [1]. Они пространственно ассоциируют с метаморфизованными металлоносными осадками (марганцевосиликатными породами, силикатно-магнетитовыми рудами) и углеродистыми силицитами триасовой кремневой 
формации Сихотэ-Алиня. Скарны (в статье используется традиционное название, несмотря на противоречие генетического содержания термина происхождению этих пород), метаморфизованные триасовые металлоносные осадки и углеродистые силициты генетически (общими источниками металлов - габброидами) связаны друг с другом, обогащены $\mathrm{Au}, \mathrm{Ag}, \mathrm{Pt}$ и $\mathrm{Pd}$ и содержат разнообразные минералы этих металлов. Минералогия благородных металлов в скарнах поли- металлических и боросиликатного месторождений Дальнегорской группы подробно охарактеризована в одной из предыдущих публикаций [2]. Целью данной работы являлось выяснение генетических особенностей Au-Ag-Pd-Pt минерализации в скарнах железорудных месторождений Ольгинского рудного района. В качестве объекта исследований было выбрано наиболее хорошо вскрытое горными выработками Белогорское месторождение (рис. 1).

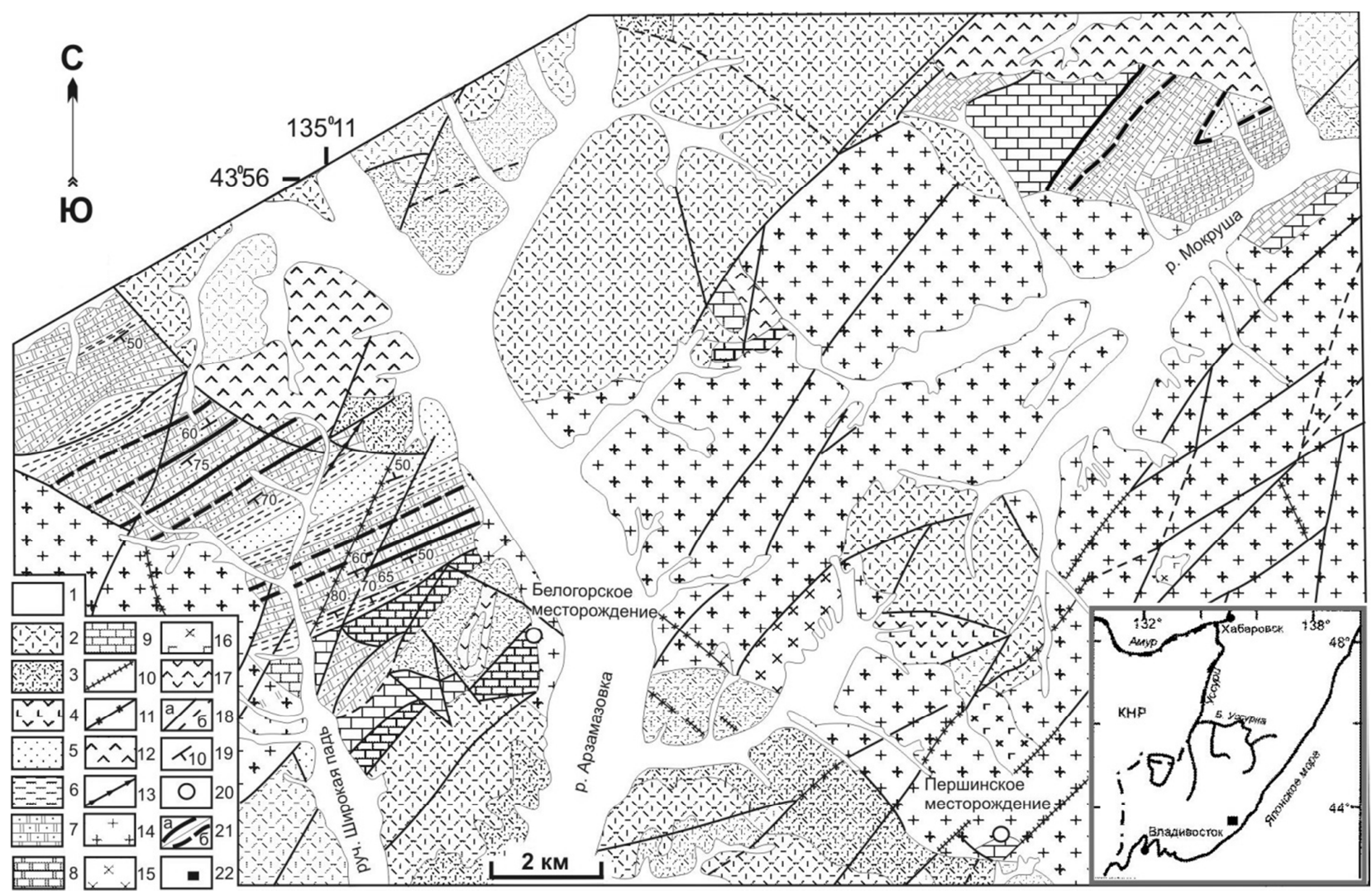

Puc. 1. Схема геологического строения фрагмента Ольгинского рудного района (по Ф. И. Ростовскому и др., 1981, с изменениями и дополнениями): 1 - четвертичные отложения; 2-5 -меловая система: 2 - богопольская свита (дат) - риолиты, риолито-дациты и их туфы, 3 - арзамазовская свита (турон-коньяк) - туфы и туфопесчаники риолитов, риолито-дацитов, 4 - синанчинская свита (сеноман) - андезиты, андезито-базальты и их туфы, 5 - песчаниковая толща $\left(\mathrm{K}_{1} ?\right) ; 6$ - юрская система $\left(\mathrm{J}_{2-3}\right)$ : алевролиты, туффиты, кремнистые породы, кремнисто-глинистые сланцы, песчаники; 7, 8 - триасовая система: 7 - терригенно-кремнистая толща $\left(\mathrm{T}_{2-3}\right), 8$ - существенно кремнистая $\left(\mathrm{T}_{1}\right) ; 9$ - верхний палеозой - известняки, глинистые сланцы, песчаники; 10 - палеоценовый плутонический комплекс - дайки диоритов, андезитов, базальтов; 11, 12 - датский вулкано-плутонический комплекс - дайки (11) и экструзии (12) риолитов, риолито-дацитов, гранит-порфиров; 13-17- позднесенонский вулкано-плутонический комплекс: 13 - дайки риолитов, аплитов и пегматитов, 14 - граниты, 15-17 - субвулканические интрузии диоритов (15), габбро-диоритов (16), дацитов (17); 18 - разломы установленные (а) и предполагаемые (б); 19 - направление и угол падения контактов интрузивных и экструзивных тел; 20 - скарново-магнетитовые месторождения; 21 - контактово-метаморфизованные металлоносные осадки (марганцевосиликатные и кремнисто-родохрозитовые породы, железные руды и яшмы): $a$ - установленное местоположение, $\sigma$ предполагаемое местоположение; 22 - (на карте - врезке) положение района исследований.

Белогорское месторождение приурочено к контакту блока позднепалеозойских рифогенных известняков и Владимирского гранитоидного массива позднемелового возраста (рис. 2), осложненному субмеридиональным тектоническим нарушением. Месторождение состоит из четырех линзовидных залежей Маргаритовской, Белогорской, Благодатной и Скальной (или Скального Отвода). На площади месторождения распространены дайки кварцевых порфиров, базальтовых, андезитовых и диабазовых порфиров, а также андезито-базальтов позднемелового-палеогенового возраста.

Минералогия месторождения рассматривалась в работах [3-7] и авторов данной статьи [8, 9]. Благодатная, Маргаритовская и Белогорская залежи сложены гранатом, магнетитом, апатитом, небольшим количеством пироксена, бустамита, везувиана и продуктами их средне-, низкотемпературного изменения хлоритом, амфиболом, карбонатом, кварцем, сульфидами, куспидином [4], флюоритом, датолитом, родо- 


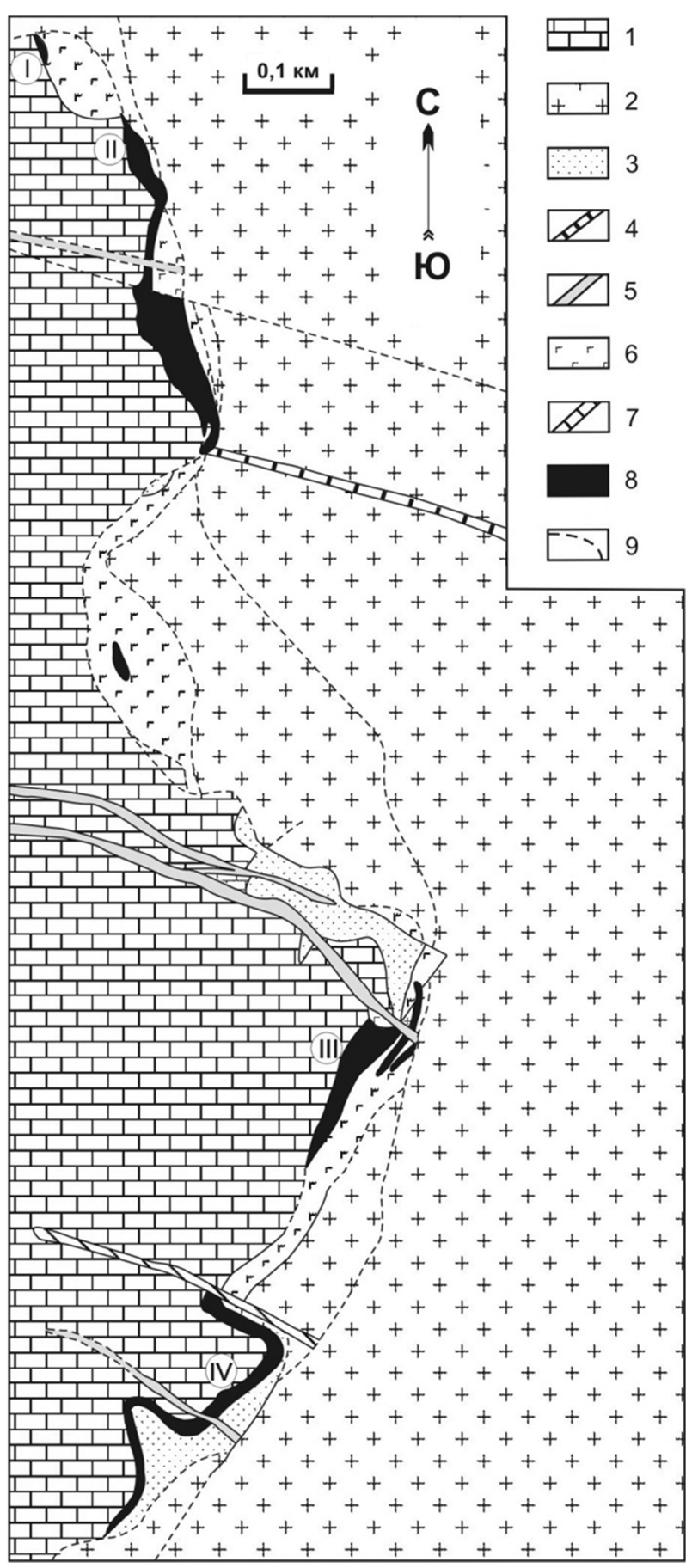

Puc. 2. Схема геологического строения Белогорского месторождения (по Бурдюгову И. С., 1945, с некоторыми упрощениями): 1 - известняки позднепалеозойского возраста; 2 - граниты Владимирского массива; 3 - измененные граниты; 4 - диабазовые порфириты; 5 - плагиоклазовые порфириты; 6 - дациты; 7 - кварцевые порфиры; 8 - скарны; 9 - тектонические нарушения. I - IV - рудные залежи Скальный отвод (I), Благодатная (II), Белогорская (III) и Маргаритовская (IV).

нитом и манганоктинолитом [8]. Фторапатит иногда слагает до 30-40 \% объема скарнов [9].

Скальная залежь приурочена к контакту известняков с кварцевыми порфирами. Она имеет форму гнез- да небольшого размера (10х7 м) с несколькими апофизами и отличается от других залежей Белогорского месторождения высоким содержанием $\mathrm{MnO}$ - до 18,6 мас. \% [9]. Залежь сложена, главным образом, богатыми Мn бустамитом, клинопироксеном и гранатом и тоже претерпела средне- и низкотемпературные изменения, выразившиеся в неравномерном замещении этих минералов карбонатом, актинолитом, кварцем и хлоритом.

\section{Методика аналитических исследований}

Содержания благородных металлов (табл. 1) были изучены с помощью атомно-абсорбционного метода в лаборатории аналитической химии ДВГИ ДВО РАН (разложение проб) и в лаборатории анализа благородных металлов (разложение проб и измерение концентраций) ДВГИ ДВО РАН. Методические особенности заключались в кислотном разложении проб, восстановлении благородных металлов $\mathrm{SnCl}_{2}$ и концентрировании на Те. Измерения концентраций проводились в графитовой кювете.

Анализы минералов (в аншлифах) (табл. 2-4) были выполнены в ДВГИ ДВО РАН на микроанализаторе JХA8100 с тремя волновыми спектрометрами и энергодисперсионным спектрометром INCAx-sight по методике, принятой в этой организации. Для обеспечения электропроводимости применялось графитовое напыление. В качестве стандартов использованы чистые металлы, зерна минералов (проанализированные другими методами), а также набор эталонов, поставляемых фирмой Agar scientific. Диагностика всех упоминаемых в работе минералов подтверждена определением их состава на рентгеноспектральном микроанализаторе. Из-за малой размерности зерен рудных минералов приведенные в таблицах результаты анализов нередко относятся к области, включающей и другие (обычно силикатные, карбонатные или оксидные) соединения. В таких случаях формулы рудных минералов рассчитаны из валового состава, без учета породообразующих элементов. Из-за возможных ошибок в определении содержания кислорода на микроанализаторе отличие самородных элементов и интерметаллидов от кислородных соединений производилось только по результатам изучения аншлифов под микроскопом в отраженном свете. Недостаток (или избыток) суммы в некоторых анализах, иногда значительный, связан с присутствием карбоната, органического вещества или пор и каверн в окружающей анализировавшееся зерно области.

\section{Полученные результаты}

По результатам анализов проб атомноабсорбционным методом для залежей Белогорского месторождения характерны повышенные содержания $\mathrm{Au}, \mathrm{Pt}$ и $\mathrm{Pd}$, достигающие 0,91, 1,54 и 2,35 г/т (проба Б-79-86), соответственно (табл. 1). Минералы благородных металлов обнаружены во всех залежах Белогорского месторождения. 
Минералогия золота, серебра, платины и палладия в залежах Белогорского железорудного месторождения ...

Таблица 1

Результаты определения содержаний благородных металлов (2/m) в скарнах Белогорского месторождения атомно-абсорбиионным методом

\begin{tabular}{|c|c|c|c|c|c|c|}
\hline $\begin{array}{c}\text { № } \\
\text { П/П }\end{array}$ & Проба & $\mathrm{Au}^{*}$ & $\mathrm{Pt}^{*}$ & $\mathrm{Pd}^{*}$ & $\mathrm{Au}^{* *}$ & $\mathrm{Pt}^{* *}$ \\
\hline 1 & Б-79-26 & 0,057 & 0,035 & н.опр. & 0,052 & 0,031 \\
\hline 2 & Б-79-49 & 0,131 & 0,051 & н.опр. & 0,172 & 0,030 \\
\hline 3 & Б-79-41 & 0,034 & 0,035 & н.опр. & 0,370 & 0,026 \\
\hline 4 & Б-79-60 & 0,061 & 0,053 & н.опр. & 0,953 & 0,016 \\
\hline 5 & Б-79-29 & 0,044 & 0,033 & н.опр. & 0,026 & 0,016 \\
\hline 6 & Б-79-30 & 0,063 & 0,042 & н.опр. & 0,050 & 0.031 \\
\hline 7 & Б-79-94 & 0,064 & 0,063 & н.опр. & 0,340 & 0,051 \\
\hline 8 & Б-79-25 & 0,018 & 0,060 & н.опр. & 0,024 & 0,029 \\
\hline 9 & Б-79-34 & 0,017 & 0,051 & н.опр. & 0,018 & 0,026 \\
\hline 10 & Б-79-33 & 0,051 & 0,030 & н.опр. & 0,012 & 0,038 \\
\hline 11 & Б-79-31 & 0,119 & 0,066 & н.опр. & 0,052 & 0,025 \\
\hline 12 & Б-79-28 & 0,106 & 0,035 & н.опр. & 0,016 & 0,024 \\
\hline 13 & Б-79-87 & 0,038 & 0,340 & н.опр. & 0,049 & 0,078 \\
\hline 14 & Б-79-62 & 0,028 & 0,038 & н.опр. & 0,046 & 0,020 \\
\hline 15 & Б-79-88 & 0,069 & 0,066 & н.опр. & 0,084 & 0,037 \\
\hline 16 & Б-79-51 & 0,032 & 0,078 & н.опр. & 0,035 & 0,021 \\
\hline 17 & Б-79-22 & 0,20 & 0,84 & 0,78 & н.опр. & н.опр. \\
\hline 18 & Б-79-86 & 0,91 & 1,54 & 2,35 & н.опр. & н.опр. \\
\hline
\end{tabular}

\begin{tabular}{|c|l|l|l|l|l|l|}
\hline $\begin{array}{c}\text { № } \\
\text { п/п }\end{array}$ & Проба & Au* & Pt* & $\mathrm{Au}^{* * *}$ & $\mathrm{Pt} * * *$ & $\mathrm{Pd}^{* * *}$ \\
\hline 19 & Б-79-92 & 0,108 & 0,044 & 0,160 & $\leq 0,001$ & 0,003 \\
\hline 20 & Б-79-93 & 0,116 & 0,055 & н.опр. & н.опр. & н.опр. \\
\hline 21 & Б-79-55 & 0,132 & 0,048 & 0,110 & 0,004 & 0,002 \\
\hline 22 & Б-79-38 & 0,191 & 0,046 & 0,055 & $\leq 0,001$ & $\leq 0,001$ \\
\hline 23 & Б-79-7 & 0,028 & 0,056 & н.опр. & н.опр. & н.опр. \\
\hline 24 & Б-79-48 & 0,021 & 0,049 & 0,160 & $\leq 0,001$ & $\leq 0,001$ \\
\hline 25 & Б-79-85 & 0,147 & 0,021 & 0,200 & $\leq 0,001$ & 0,003 \\
\hline 26 & Б-79-84 & 0,042 & 0,378 & 0,150 & $\leq 0,001$ & $\leq 0,001$ \\
\hline 27 & Б-79-59 & 0,070 & 0,029 & 0,180 & 0,002 & 0,002 \\
\hline 28 & Б-79-98 & 0,024 & 0,035 & 0,090 & $\leq 0,001$ & $\leq 0,001$ \\
\hline 29 & Б-79-2 & 0,054 & 0,053 & 0,420 & $\leq 0,001$ & $\leq 0,001$ \\
\hline 30 & Б-79-32 & 0,017 & 0,088 & 0,240 & $\leq 0,001$ & $\leq 0,001$ \\
\hline 31 & Б-79-96 & 0,021 & 0,039 & 0,120 & $\leq 0,001$ & $\leq 0,001$ \\
\hline 32 & Б-79-75 & 0,297 & 0,068 & н.опр. & н.опр. & н.опр. \\
\hline 33 & Б-79-16 & 0,109 & 0,049 & 0,130 & $\leq 0,001$ & $\leq 0,001$ \\
\hline 34 & Б-79-37 & 0,184 & 0,084 & 0,130 & $\leq 0,001$ & $\leq 0,001$ \\
\hline 35 & Б-79-85 & 0,106 & 0,087 & н.опр. & н.опр. & н.опр. \\
\hline
\end{tabular}

Примечание: * и ** (первоначальные и повторные анализы, соответственно) - разложение проб производилось в лаборатории аналитической химии ДВГИ ДВО РАН, а измерения - в лаборатории микро- и наноисследований ДВГИ ДВО РАН. *** - разложение проб и измерения производились в лаборатории микро- и наноисследований ДВГИ ДВО РАН. н.опр. - не определялось.

Таблица 2

Результаты изучения неупорядоченных твердых растворов и интерметаллических соединений золота, платинь и палладия в Маргаритовской и Скальной залежах с помощью рентгеноспектрального микроанализатора (мас. \%)

\begin{tabular}{|c|c|c|c|c|c|c|c|c|c|c|c|c|c|c|c|c|}
\hline № & Образец & $\mathrm{O}$ & $\mathrm{Mg}$ & $\mathrm{Al}$ & $\mathrm{Si}$ & $\mathrm{Ca}$ & $\mathrm{Mn}$ & $\mathrm{Fe}$ & $\mathrm{Co}$ & $\mathrm{Cu}$ & $\mathrm{Zn}$ & $\mathrm{Pd}$ & $\mathrm{Ag}$ & $\mathrm{Au}$ & $\mathrm{Pt}$ & Сумма \\
\hline 1 & \multirow{2}{*}{ Б-79-25 } & 26,83 & 0,29 & 0,61 & 11,67 & 15,46 & 0,62 & 12,94 & & 7,43 & & & 1,73 & 19,6 & & $\begin{array}{l}97,18 \\
\end{array}$ \\
\hline 2 & & 13,37 & & 0,32 & 2,69 & 4,25 & & 10,1 & & 2,32 & & & 1,28 & 65,78 & & 100,12 \\
\hline 3 & \multirow{7}{*}{ Б-79-35 } & 22,12 & & & & 0,22 & & 50,08 & & & & & 2,34 & 27,14 & & 101,89 \\
\hline 4 & & 7,97 & & & & 0,66 & & 12,58 & 0,73 & & 0,53 & & & 75,21 & & 97,68 \\
\hline 5 & & 16,16 & & & & 0,35 & & 44,64 & & & & & & 36,01 & & 97,59 \\
\hline 6 & & 9,03 & & & 2,6 & 0,38 & & 20,55 & & 6,93 & & & & 59,54 & & 99,03 \\
\hline 7 & & 7,85 & & & & 2,93 & & 9 & 0,94 & 0,88 & 0,77 & & & 80,92 & & 103,28 \\
\hline 8 & & 17,3 & & & & 3,08 & & 14,1 & & 2,51 & 1,25 & & & 62,15 & & 100,39 \\
\hline 9 & & 11,31 & & & & 1,88 & & 14,88 & & 1,18 & & & & 69,85 & & 99,1 \\
\hline 10 & Ш-86-159 & 26,06 & 0,93 & & 5,15 & 4,08 & 2,56 & 3,99 & & & & 44,22 & 15,31 & & & 102,3 \\
\hline 11 & \multirow{4}{*}{$\begin{array}{c}\amalg-86-146 \\
(2)\end{array}$} & 37,29 & & 15,41 & 3,19 & 10,36 & & 0,59 & & & & & 1,98 & 7,29 & & 76,49 \\
\hline 12 & & 28,59 & & 3,98 & 3,38 & 6,22 & & 0,54 & & & & & 16,9 & 37,21 & & 96,81 \\
\hline 13 & & 33,97 & & 4,76 & 2,59 & 6,64 & & 0,63 & & & & & 13,21 & 33,32 & & 95,13 \\
\hline 14 & & 26,24 & 0,23 & 8,54 & 3,36 & 6,7 & & 0,95 & & & & & 6,92 & 18,76 & & 71,97 \\
\hline 15 & \multirow{7}{*}{ Ш-86-151 } & 35,68 & & & 1,59 & 28,89 & 1,58 & 1,49 & & 4,78 & & & 0,7 & 7,74 & & 82,44 \\
\hline 16 & & 34,11 & & 9,31 & 16,08 & 17,73 & 2,78 & 2,84 & & & & 6,7 & & & 10,86 & 100,80 \\
\hline 17 & & 9,23 & & & 2,48 & 0,96 & & 12,21 & & & & & & 45,91 & & 70,78 \\
\hline 18 & & 14,88 & 0,74 & 3,73 & 7,02 & 10,35 & 1,26 & 4,01 & & 8,98 & & & 2,19 & 16,6 & & 69,76 \\
\hline 19 & & 9,13 & 0,66 & & 4,04 & 2,18 & 0,77 & 7,98 & & & & & & & 39,67 & 64,43 \\
\hline 20 & & 32,3 & 3,81 & 1,32 & 20,5 & 6,63 & 1,73 & 15,22 & & 12,33 & & & 0,72 & & & 95,8 \\
\hline 21 & & 30,61 & 3,32 & 1,23 & 18,66 & 5,81 & 1,67 & 12,63 & & 19,86 & & & 1,15 & & & 97,8 \\
\hline 22 & \multirow{3}{*}{ Шп-80-15 } & 35,85 & & 0,22 & 24,43 & & 4,53 & 0,48 & & & & 29,98 & 8,13 & & & 103,63 \\
\hline 23 & & 33,96 & & 0,25 & & & 7,77 & 0,39 & 0,74 & 0,61 & & & & 42,68 & & 86,4 \\
\hline 24 & & 6,41 & & & & & 3,06 & 2,76 & & 10,48 & & & & 68,95 & & 91,65 \\
\hline
\end{tabular}

Примечания: кроме того, в анализах (мас.\%): 5 - 0,43 Na; 11 и $14-0,38$ и 0,27 Тi, соответственно; $16-0,37 \mathrm{Na} 220$ - 1,24 P; 21 - 1,61 Р и 1,25 Sn. Залежи: Маргаритовская (1-9), Скальная (10-24). Минералы: 1 - купроаурид; 2-5, 7-9, 12-14, 17, 20, 21,23 - неупорядоченные твердые растворы на основе золота; 6, 15, 18, 24 - неупорядоченные твердые растворы или, возможно, интерметаллические соединения $\mathrm{CuAu}_{3}(6), \mathrm{Cu}_{2} \mathrm{Au}(15), \mathrm{Cu}_{4}(\mathrm{Au}, \mathrm{Ag})_{3}(18), \mathrm{CuAu}_{2}(24) ; 10-\mathrm{Pd}_{3} \mathrm{Ag}, 16-\mathrm{PdPt}, 19-$ самородная платина, $22-\mathrm{Pd}_{4} \mathrm{Ag}$. Формулы: $1-\mathrm{Cu}_{1,00}\left(\mathrm{Au}_{0,86} \mathrm{Ag}_{0,14}\right)_{1,00} ; 2-\mathrm{Au}_{0,86} \mathrm{Cu}_{0,09} \mathrm{Ag}_{0,05} ; 3-\mathrm{Au}_{0,86} \mathrm{Ag}_{0,14} ; 4-$ 
$\mathrm{Au}_{0,95} \mathrm{Co}_{0,03} \mathrm{Zn}_{0,02} ; 5-\mathrm{Au}_{1,00} ; 6-\mathrm{Au}_{0,65} \mathrm{Cu}_{0,35}$ или $\mathrm{Cu}_{1,06} \mathrm{Au}_{2,94} ; 7-\mathrm{Au}_{0,91} \mathrm{Co}_{0,04} \mathrm{Cu}_{0,03} \mathrm{Zn}_{0,02} ; 8-\mathrm{Au}_{0,84} \mathrm{Cu}_{0,11} \mathrm{Zn}_{0,05} ; 9-\mathrm{Au}_{0,95} \mathrm{Cu}_{0,05} ; 10$ $-\mathrm{Pd}_{2,98} \mathrm{Ag}_{1,02} ; 11-\mathrm{Au}_{0,67} \mathrm{Ag}_{0,33} ; 12-\mathrm{Au}_{0,55} \mathrm{Ag}_{0,45} ; 13-\mathrm{Au}_{0,58} \mathrm{Ag}_{0,42} ; 14-\mathrm{Au}_{0,60} \mathrm{Ag}_{0,40} ; 15-\mathrm{Cu}_{0,63} \mathrm{Au}_{0,32} \mathrm{Ag}_{0,05} \mathrm{uли}$ $\left(\mathrm{Cu}_{1,87} \mathrm{Ag}_{0,16}\right)_{2,03} \mathrm{Au}_{0,97} ; 16-\mathrm{Pd}_{1,06} \mathrm{Pt}_{0,94} ; 17-\mathrm{Au}_{1,00} ; 18-\mathrm{Cu}_{0,58} \mathrm{Au}_{0,34} \mathrm{Ag}_{0,08}$ или $\mathrm{Cu}_{4,02}\left(\mathrm{Ag}_{0,58} \mathrm{Au}_{2,40}\right)_{2,98} ; 19-\mathrm{Pt}_{1,00} ; 20-\mathrm{Cu}_{0,97} \mathrm{Ag}_{0,03}$; $21-\mathrm{Cu}_{0,94} \mathrm{Ag}_{0,03} \mathrm{Sn}_{0,03} ; 22-\mathrm{Pd}_{3,95} \mathrm{Ag}_{1,05} ; 23-\mathrm{Au}_{0,91} \mathrm{Co}_{0,05} \mathrm{Cu}_{0,04} ; 24-\mathrm{Au}_{0,68} \mathrm{Cu}_{0,32}$ или $\mathrm{Cu}_{0,96} \mathrm{Au}_{2,04}$.

Таблица 3

Результаты изучения минералов золота и платинь в Белогорской и Благодатной залежах с помощью рентгеноспектрального микроанализатора (мас. \%)

\begin{tabular}{|c|c|c|c|c|c|c|c|c|c|c|c|c|c|c|c|c|}
\hline № & Образец & $\mathrm{O}$ & $\mathrm{Na}$ & $\mathrm{Mg}$ & $\mathrm{Al}$ & $\mathrm{Si}$ & $\mathrm{Ca}$ & $\mathrm{Mn}$ & $\mathrm{Fe}$ & Co & $\mathrm{Cu}$ & $\mathrm{Zn}$ & $\mathrm{Ag}$ & $\mathrm{Au}$ & $\mathrm{Pt}$ & Сумма \\
\hline 1 & \multirow{3}{*}{ Б-79-14 } & 7,8 & 0,8 & & 1,6 & 3,13 & 5,45 & & 1,95 & 0,53 & 0,5 & & & 80,28 & & 102,05 \\
\hline 2 & & 32,44 & & 0,39 & 7,18 & 14,09 & 16,19 & 0,41 & 4,76 & & 5,9 & & 1,15 & 16,81 & & 99,31 \\
\hline 3 & & 27,36 & & & 6,66 & 11,62 & 18,27 & 0,32 & 2,6 & & & & & 31,87 & & 98,72 \\
\hline 4 & \multirow{4}{*}{ Б-79-55 } & 14,17 & & & & 6,03 & 10,83 & & 10,18 & & 0,44 & & & 39,38 & & 81,57 \\
\hline 5 & & 14,59 & & & & 5,78 & 10,61 & & 8,6 & & & & & 63,21 & & 101,80 \\
\hline 6 & & 8,25 & & & & & 0,41 & & 13,98 & 1,27 & & 0,63 & & 79,32 & & 103,85 \\
\hline 7 & & 17,8 & & & & 5,81 & 10,01 & 0,43 & 9,76 & & 0,63 & & & 59,17 & & 103,61 \\
\hline 8 & \multirow{2}{*}{ Б-79-74 } & 29,34 & & & & 12,41 & 21,9 & 1,58 & 17,94 & & & & & & 11,18 & 94,36 \\
\hline 9 & & 16,38 & & & & 8 & 13,03 & 0,37 & 11,48 & & & & 7,44 & 44,06 & & 100,76 \\
\hline 10 & \multirow{15}{*}{ Б-79 } & 7,08 & 0,37 & & & & 0,6 & & 24,24 & & 0,61 & & & 26,88 & & 59,79 \\
\hline 11 & & 29,15 & & & & & 0,38 & & 42,08 & 0,53 & & 1,94 & & 22,84 & & 96,93 \\
\hline 12 & & 16,44 & & & & & 0,22 & & 41,42 & & 2,05 & & & 34,28 & & 94,41 \\
\hline 13 & & 5,64 & & & & & 0,63 & & 18,14 & & 6,19 & & & 50,72 & & 81,33 \\
\hline 14 & & 5,57 & & & 0,06 & 1,06 & 12,8 & & 2,76 & & & & & 26,03 & & 53,65 \\
\hline 15 & & 13,33 & & & 0,18 & & & & 45,78 & & & & 6,08 & 20,29 & & 85,67 \\
\hline 16 & & 10,11 & & & & & 0,31 & & 26,33 & & & 1,57 & & 60,52 & & 98,83 \\
\hline 17 & & 5,07 & 0,85 & & & & & & 12,03 & 1,09 & & 1,11 & & 78,27 & & 98,43 \\
\hline 18 & & 9,37 & & & & & 0,31 & & 33,21 & & 5,1 & & & 38,36 & & 86,35 \\
\hline 19 & & 23,54 & & & 0,2 & 0,26 & 0,68 & & 30,33 & & 0,51 & & & & 32,2 & 87,73 \\
\hline 20 & & 23,46 & & 0,12 & & 0,29 & 0,77 & & 27,39 & & & & & & 38,6 & 90,63 \\
\hline 21 & & 25,73 & & & & & 0,47 & & 37,42 & & 3 & & & 29,77 & & 96,39 \\
\hline 22 & & 31,74 & & & 0,07 & & & & 45,06 & & & & 5,99 & 18,92 & & 101,61 \\
\hline 23 & & 25,45 & & & & & 0,42 & & 36,45 & & 4,04 & & & 27,02 & & 93,39 \\
\hline 24 & & 13,82 & & & & & 0,58 & & 24,39 & & 4,82 & & & 56,91 & & 100,51 \\
\hline 25 & \multirow{2}{*}{ Б-79-3 } & 12,59 & & & & & 12,08 & 2,02 & 1,13 & & 1,16 & & 5,12 & 51,52 & & 85,63 \\
\hline 26 & & 2,78 & & & & 0,41 & & & 0,57 & & 1,07 & & 86,93 & & & 91,75 \\
\hline 27 & \multirow{2}{*}{ Б-79-24 } & 27,32 & & 1,91 & 3,46 & 5,44 & 0,78 & 0,94 & 12,7 & & & & 10,39 & 35,92 & & 98,88 \\
\hline 28 & & 4,81 & & & 0,59 & 1,49 & 2,08 & & 1,73 & & 4,35 & & 85,22 & & & 101,01 \\
\hline
\end{tabular}

Примечания: кроме того, в анализах (мас. \%): 14 - 3,97 Р и 1,39 Те; 28 - 0,74 Те. Залежи: Белогорская (1-3), Благодатная (4-28). Минералы: 1, 3-7, 9-12, 14-18, 22, 25, 27 - неупорядоченные твердые растворы на основе Аu; 2 -купроаурид; 8, 19 , 20 - самородная платина; $13,21,23,24$ - неупорядоченный твердый раствор или интерметаллическое соединение СuАu $; 26$, 28 - самородное серебро. Формуль: 1 - $\mathrm{Au}_{0,96} \mathrm{Cu}_{0,02} \mathrm{Co}_{0,02} ; 2-\mathrm{Cu}_{0,99}\left(\mathrm{Au}_{0,90} \mathrm{Ag}_{0,11}\right)_{1,01} ; 3-\mathrm{Au}_{1,00} ; 4-\mathrm{Au}_{0,97} \mathrm{Cu}_{0,03} ; 5-\mathrm{Au}_{1,00} ; 6-$ $\mathrm{Au}_{0,93} \mathrm{Co}_{0,05} \mathrm{Zn}_{0,02} ; 7-\mathrm{Au}_{0,97} \mathrm{Cu}_{0,03} ; 8-\mathrm{Pt}_{1,00} ; 9-\mathrm{Au}_{0,76} \mathrm{Ag}_{0,24} ; 10-\mathrm{Au}_{0,93} \mathrm{Cu}_{0,07} ; 11-\mathrm{Au}_{0,75} \mathrm{Zn}_{0,19} \mathrm{Co}_{0,06} ; 12-\mathrm{Au}_{0,84} \mathrm{Cu}_{0,16} ; 13-$ $\mathrm{Au}_{0,73} \mathrm{Cu}_{0,27}$ или $\mathrm{Cu}_{1,10} \mathrm{Au}_{2,90} ; 14-\mathrm{Au}_{0,92} \mathrm{Te}_{0,08} ; 15-\mathrm{Au}_{0,65} \mathrm{Ag}_{0,35} ; 16-\mathrm{Au}_{0,93} \mathrm{Zn}_{0,07} ; 17-\mathrm{Au}_{0,92} \mathrm{Co}_{0,04} \mathrm{Zn}_{0,04} ; 18-\mathrm{Au}_{0,71} \mathrm{Cu}_{0,29} ; 19-$ $\mathrm{Pt}_{0,95} \mathrm{Cu}_{0,05} ; 20-\mathrm{Pt}_{1,00} ; 21-\mathrm{Au}_{0,76} \mathrm{Cu}_{0,24}$ или $\mathrm{Cu}_{0,95} \mathrm{Au}_{3,05} ; 22-\mathrm{Au}_{0,63} \mathrm{Ag}_{0,37} ; 23-\mathrm{Au}_{0,76} \mathrm{Cu}_{0,24}$ или $\mathrm{Cu}_{0,95} \mathrm{Au}_{3,05} ; 24-\mathrm{Au}_{0,79} \mathrm{Cu}_{0,21}$ или $\mathrm{Cu}_{0,83} \mathrm{Au}_{3,17} ; 25-\mathrm{Au}_{0,80} \mathrm{Ag}_{0,14} \mathrm{Cu}_{0,06} ; 26-\mathrm{Ag}_{0,98} \mathrm{Cu}_{0,02} ; 27-\mathrm{Au}_{0,65} \mathrm{Ag}_{0,35} ; 28-\mathrm{Ag}_{0,91} \mathrm{Cu}_{0,08} \mathrm{Te}_{0,01}$.

Таблица 4

Результаты изучения серебросодержащих минералов с помощью рентгеноспектрального микроанализатора (мас. \%)

\begin{tabular}{|c|c|c|c|c|c|c|c|c|c|c|c|c|c|c|c|c|}
\hline № & Образец & $\mathrm{O}$ & $\mathrm{Mg}$ & $\mathrm{Si}$ & $\mathrm{S}$ & $\mathrm{Ca}$ & $\mathrm{Mn}$ & $\mathrm{Fe}$ & $\mathrm{Cu}$ & $\mathrm{Zn}$ & $\mathrm{Ag}$ & $\mathrm{Sb}$ & $\mathrm{Te}$ & $\mathrm{Pb}$ & $\mathrm{Bi}$ & Сумма \\
\hline 1 & 2 & 3 & 4 & 5 & 6 & 7 & 8 & 9 & 10 & 11 & 12 & 13 & 14 & 15 & 16 & 17 \\
\hline 1 & Б-79-14 & 11,6 & & 4,29 & 15,96 & 5,36 & & 5,26 & 11,78 & 0,67 & 21,56 & 18,59 & & & & 98,54 \\
\hline 2 & Б-79-74 & & & & 16,43 & 0,59 & & & & & 0,65 & & & & 72,61 & 90,9 \\
\hline 3 & \multirow{4}{*}{ Б-79-3 } & 2,64 & & & 11,57 & 0,3 & & & & 1,01 & 8,09 & & & 33,88 & 35,65 & 93,50 \\
\hline 4 & & 7 & & & 10,1 & 5,99 & 0,71 & & & & 1,57 & & 0,93 & 33,31 & 32,61 & 92,7 \\
\hline 5 & & 27,3 & & & 4,49 & 25,14 & 4,2 & & & & 2,06 & & 1,9 & & 26,1 & 91,77 \\
\hline 6 & & & & & 15,5 & & & & & 3,35 & 9,84 & & & 25,37 & 49,82 & 103,88 \\
\hline 7 & \multirow{3}{*}{ Б-79-24 } & 7,27 & & & 12,8 & 0,51 & & & & & 2,43 & & & 40,32 & 33,91 & 98,47 \\
\hline 8 & & 4,82 & & & 13,86 & 0,43 & & & & & 1,71 & & & 37,67 & 40,96 & 103,44 \\
\hline 9 & & 11,4 & & 1,85 & 10,54 & 1,11 & & 2,02 & 3,93 & & 48,27 & 4,42 & & & & 85,88 \\
\hline 10 & \multirow{2}{*}{ Б-79-43 } & 16,20 & & 14,16 & 9,18 & 0,36 & & & & & 3,15 & & & 23,70 & 33,73 & 100,48 \\
\hline 11 & & 5,14 & & 0,81 & 13,34 & 0,69 & & & & & 8,03 & & & 19,52 & 47,96 & 96,89 \\
\hline
\end{tabular}


Продолжение табл. 4

\begin{tabular}{|c|c|c|c|c|c|c|c|c|c|c|c|c|c|c|c|c|}
\hline 1 & 2 & 3 & 4 & 5 & 6 & 7 & 8 & 9 & 10 & 11 & 12 & 13 & 14 & 15 & 16 & 17 \\
\hline 12 & \multirow{6}{*}{ Ш-86-151 } & 29,89 & & 2,64 & & 14,86 & 0,65 & 2,05 & & 2,52 & 3,11 & & 1,29 & 15,84 & 31,15 & 100,34 \\
\hline 13 & & 25,27 & & 1,1 & & 7,56 & 2,92 & 1,36 & & 2,49 & 3,91 & & & 9,11 & 43,48 & 97,19 \\
\hline 14 & & 31,81 & 0,83 & 3,98 & 3,45 & 22,9 & 3,26 & 3,14 & & & 0,97 & & & 9,5 & 9,78 & 89,64 \\
\hline 15 & & 27,08 & 0,94 & 7,97 & & 4,9 & 1,19 & 4,36 & & 0,82 & 1,26 & & & & 50,55 & 98,69 \\
\hline 16 & & 42,2 & 1,53 & 31,27 & 2,86 & 2,78 & 0,89 & 5,47 & & & 1 & & & 6,04 & 9,35 & 103,39 \\
\hline 17 & & 35,56 & & 31,77 & & 0,64 & & 0,45 & & & 1,31 & & & & 16,68 & 86,41 \\
\hline
\end{tabular}

Примечания: кроме того, в анализах (мас. \%): $1-2,6 \mathrm{Al}$ и $0,84 \mathrm{Cr} ; 4-0,48 \mathrm{Na} ; 9-1,16 \mathrm{Al}$ и 1,21 Аs. Залежи: Благодатная (1-9), Маргаритовская (10-11), Скальная (12-17). Минералы: 1 - блеклая руда; 2 - висмутин; 3, 4, 6-8, 10, 11, 14, 16( $\mathrm{Pb}, \mathrm{Ag}) \mathrm{BiS}_{2} ; 5$ - (Bi,Ag)(S,Te); 9 - полибазит; 12, 13, 15, 17 - висмут; Формуль: 1 - $\left(\mathrm{Cu}_{9,24} \mathrm{Ag}_{9,95} \mathrm{Zn}_{0,52} \mathrm{Fe}_{4,69}\right)_{24,40} \mathrm{Sb}_{7,60} \mathrm{~S}_{24,79} ; 2$ $\left(\mathrm{Bi}_{2,00} \mathrm{Ag}_{0,04}\right)_{2,04} \mathrm{~S}_{2,96} ; 3-\left(\mathrm{Pb}_{0,85} \mathrm{Ag}_{0,39}\right)_{1,24} \mathrm{Bi}_{0,89} \mathrm{~S}_{1,87} ; 4-\left(\mathrm{Pb}_{0,98} \mathrm{Ag}_{0,09}\right)_{1,07}\left(\mathrm{Bi}_{0,95} \mathrm{Te}_{0,05}\right)_{1,00} \mathrm{~S}_{1,93} ; 5-\left(\mathrm{Bi}_{0,84} \mathrm{Ag}_{0,13}\right)_{0,97}\left(\mathrm{~S}_{0,93} \mathrm{Te}_{0,10}\right)_{1,03} ; 6-$ $\left(\mathrm{Pb}_{0,52} \mathrm{Ag}_{0,39}\right)_{0,91} \mathrm{Bi}_{1,02} \mathrm{~S}_{2,07} ; 7-\left(\mathrm{Pb}_{1,00} \mathrm{Ag}_{0,12}\right)_{1,12} \mathrm{Bi}_{0,83} \mathrm{~S}_{2,05} ; 8-\left(\mathrm{Pb}_{0,88} \mathrm{Ag}_{0,08}\right)_{0,96} \mathrm{Bi}_{0,95} \mathrm{~S}_{2,09} ; 9-\left(\mathrm{Ag}_{14,57} \mathrm{Cu}_{2,02}\right)_{16,59}\left(\mathrm{Sb}_{1,19} \mathrm{As}_{0,52}\right)_{1,71} \mathrm{~S}_{10,70}$; $10-\left(\mathrm{Pb}_{0,77} \mathrm{Ag}_{0,20}\right)_{0,97} \mathrm{Bi}_{1,09} \mathrm{~S}_{1,94} ; 11-\left(\mathrm{Pb}_{0,46} \mathrm{Ag}_{0,37}\right)_{0,83} \mathrm{Bi}_{1,13} \mathrm{~S}_{2,04} ; 12-\mathrm{Bi}_{0,49} \mathrm{~Pb}_{0,25} \mathrm{Te}_{0,03} \mathrm{Zn}_{0,13} \mathrm{Ag}_{0,10} ; 13-\mathrm{Bi}_{0,64} \mathrm{~Pb}_{0,13} \mathrm{Zn}_{0,12} \mathrm{Ag}_{0,11} ; 14-$ $\left(\mathrm{Pb}_{0,85} \mathrm{Ag}_{0,17}\right)_{1,02} \mathrm{Bi}_{0,86} \mathrm{~S}_{1,98} ; 15-\mathrm{Bi}_{0,91} \mathrm{Zn}_{0,05} \mathrm{Ag}_{0,04} ; 16-\left(\mathrm{Pb}_{0,68} \mathrm{Ag}_{0,21}\right)_{0,89} \mathrm{Bi}_{1,04} \mathrm{~S}_{2,07} ; 17-\mathrm{Bi}_{0,87} \mathrm{Ag}_{0,13}$.

Маргаритовская залежь. Золото встречается в виде неупорядоченного твердого раствора $\mathrm{Au}$ и $\mathrm{Cu}$ $\left(\mathrm{Cu}_{0,35} \mathrm{Au}_{0,65}\right)$ или, возможно, интерметаллического соединения $\mathrm{CuAu}_{3}$ (по анализу, $\mathrm{Cu}_{1,06} \mathrm{Au}_{2,94}$ ), а также купроаурида, содержащего немного $\mathrm{Ag}$ (табл. 2). Минерал $\mathrm{CuAu}_{3}$, отвечающий кубической модификации $[10,11]$, не имеет утверждённого названия.

В Маргаритовской залежи обнаружены также самородное $\mathrm{Au}$ без примесей, высокопробный $\mathrm{Au}-\mathrm{Ag}$ твердый раствор, самородное $\mathrm{Au}$ с примесью меди, меди и цинка, кобальта и цинка, а также меди, кобальта и цинка. Минералы Аu присутствуют в виде многочисленных зерен диаметром до 10 мкм. Серебро присутствует в виде сульфида, иногда обогащенного $\mathrm{Cu}$ (до 0,12 ф.е.) (табл. 4). Встречаются богатый $\mathrm{Ag}$ тетраэдрит, и, предположительно, гидроксид-хлорид $\left(\mathrm{Ag}_{0,32-0,24} \mathrm{~Pb}_{1,28-1,26} \mathrm{Bi}_{0,40-0,50}\right)_{2,00} \mathrm{O}(\mathrm{OH}) \mathrm{Cl}_{1,02-1,04}$ экзогенного происхождения, а также соединение $(\mathrm{Pb}, \mathrm{Ag}) \mathrm{BiS}_{2}$, анализы которого соответствуют общей формуле $\left(\mathrm{Pb}_{0,77-0,49} \mathrm{Ag}_{0,20-0,34}\right)_{0,97-0,83} \mathrm{Bi}_{1,09-1,13} \mathrm{~S}_{1,94-2,04}$. Оно встречается довольно часто и по составу близко к козалиту. Однако в его анализах постоянно присутствует Ag и отмечается недостаток $\mathrm{S}$ по сравнению с теоретической формулой козалита $\mathrm{Pb}_{2} \mathrm{Bi}_{2} \mathrm{~S}_{5}$, вследствие чего они хорошо рассчитываются на теоретическую формулу $(\mathrm{Pb}, \mathrm{Ag}) \mathrm{BiS}_{2}$. Эта формула близка к формуле матильдита, но предполагает присутствие значительного количества $\mathrm{Pb}$ и вхождение части Вi в двухвалентном состоянии. Подобный минерал ранее был обнаружен в рудах Болотистого золоторудного месторождения (Хабаровский край) [12]. В Маргаритовской залежи встречается и козалит, анализы которого хорошо пересчитываются на идеальную формулу $\mathrm{Pb}_{2} \mathrm{Bi}_{2} \mathrm{~S}_{5}$, но этот минерал совсем не содержит серебра. Серебро, кроме того, входит в состав купроаурида и самородного золота. Высокое содержание Ag (до 4,8 \% массы), обусловленное, возможно, микровключениями серебряных минералов, иногда отмечается в анализах галенита.

Белогорская залежь. Минералы Аu (табл. 3) представлены купроауридом, самородным Аu без примесей, Au c примесью кобальта или меди и кобальта. Серебро присутствует в купроауриде, а также в виде сульфида, в том числе его Те-содержащей разновидности. Встречается очень богатая Ag разновидность тетраэдрита (табл. 4).

Благодатная залежь. В этой залежи распространено самородное $\mathrm{Au}$, не содержащее примеси других элементов (табл. 3), а также $\mathrm{Cu}$-содержащая, Znсодержащая, Zn-, и Со-содержащая и Те-содержащая разновидности. Встречаются неупорядоченные твердые растворы золота и серебра, золота, серебра и меди, а также неупорядоченные твердые растворы золота и меди, или, возможно, интерметаллические соединения, близкие по составу к $\mathrm{CuAu}_{3}\left(\mathrm{Cu}_{1,10-0,83} \mathrm{Au}_{2,90-}\right.$ 3,17) и $\mathrm{CuAu}_{2}\left(\mathrm{Cu}_{0,87-0,95} \mathrm{Au}_{2,13-2,05}\right)$. Минералы $\mathrm{Ag}$ представлены хлораргиритом экзогенного происхождения и As-содержащей разновидностью полибазита (табл. 4). Обнаружены необычная (с Ag) разновидность висмутина, соединение $\mathrm{Ag}_{4} \mathrm{Sb}_{2} \mathrm{~S}_{3}$ (?) (или, по анализу $\left.\mathrm{Ag}_{4,01} \mathrm{Sb}_{2,00} \mathrm{~S}_{2,99}\right)$, образующее столбчатые кристаллы, и богатый $\mathrm{Ag}$ (до 34,76 \% массы) тетраэдрит. Присутствуют самородное $\mathrm{Ag}$ и его $\mathrm{Cu}-$ содержащая разновидность, уже упоминавшееся соединение $(\mathrm{Pb}, \mathrm{Ag}) \mathrm{BiS}_{2} \quad$ состава $\quad\left(\mathrm{Pb}_{0,84-0,98} \mathrm{Ag}_{0,39-0,08}\right)_{1,24-1,06} \mathrm{Bi}_{0,88-}$ ${ }_{0,96}\left(\mathrm{~S}_{1,87-1,96} \mathrm{Te}_{0,00-0,04}\right)_{1,90-2,00}$, иногда в качестве включений в кобальтине или в ассоциации с фазой $\left(\mathrm{Bi}_{0,84} \mathrm{Ag}_{0,13}\right)_{0,97}\left(\mathrm{~S}_{0,93} \mathrm{Te}_{0,10}\right)_{1,03}$. Анализ последнего минерала, диагностика которого требует уточнения, удовлетворительно пересчитывается и на идеальную формулу $\mathrm{AgBi}_{5}(\mathrm{~S}, \mathrm{Te})_{6}-\mathrm{Ag}_{0,78} \mathrm{Bi}_{5,04}\left(\mathrm{~S}_{5,58} \mathrm{Te}_{0,60}\right)_{6,18}$. Ceребро присутствует в самородном $\mathrm{Au}$. Высокое содержание этого металла (до 2,5 мас. \%), обусловленное, возможно, микровключениями серебряных минералов, иногда отмечается в анализах галенита. Минеральные формы элементов платиновой группы представлены самородной $\mathrm{Cu}$-содержащей платиной, соединением $\mathrm{Ru}(\mathrm{Pb}, \mathrm{Ag})_{2} \mathrm{Bi}_{4}$ (?), или (по анализу) $\mathrm{Ru}_{0,98}\left(\mathrm{~Pb}_{1,54} \mathrm{Ag}_{0,49}\right)_{2,03} \mathrm{Bi}_{3,99}$, a также $\mathrm{Rh}$-содержащими кислородными соединениями $\mathrm{Pb}$. Встречается самородная платина, не содержащая примеси других элементов, за исключением, возможно, железа, количество которого не поддается определению из-за малой размерности зерен и высокого содержания железа в окружающих их минералах.

Залежь Скальный Отвод. Минералы Аu в этой 
залежи представлены самородным Аu без примесей (табл. 2), а также $\mathrm{Cu}$ - и Со-содержащей разновидностью. Распространены неупорядоченные твердые растворы или, возможно, интерметаллические соединения золота и меди, близкие по составу к $\mathrm{Cu}_{2} \mathrm{Au}$, купроауриду, $\mathrm{Cu}_{4} \mathrm{Au}_{3}$, и $\mathrm{CuAu}_{2}$. Встречается $\mathrm{Au}-\mathrm{Ag}$ твердый раствор и его Те-содержащая разновидность. Минералы Ag представлены самородным Ag, сульфидом Ag, соединениями, анализы которых пересчитываются на идеальные формулы $\mathrm{Pd}_{3} \mathrm{Ag}$ (в ассоциации с галенитом и сфалеритом) и $\mathrm{Pd}_{4} \mathrm{Ag}$ (табл. 4). Встречаются оксид (?) $\mathrm{Bi}, \mathrm{Pb}, \mathrm{Ag}$ и $\mathrm{Zn}$ экзогенного происхождения, скопления игольчатых кристаллов соединения $(\mathrm{Pb}, \mathrm{Ag}) \mathrm{BiS}_{2}, \mathrm{Ag}$-содержащая самородная медь, упомянутое выше соединение (Bi, $\mathrm{Ag})(\mathrm{S}, \mathrm{Te})$ $\left(\mathrm{Bi}_{0,88} \mathrm{Ag}_{0,13}\right)_{1,01} \mathrm{~S}_{0,99}$, или $\mathrm{AgBi}_{5} \mathrm{~S}_{6}\left(\mathrm{Ag}_{0,78} \mathrm{Bi}_{5,28} \mathrm{~S}_{5,94}\right)$. Ceребро присутствует в самородном и «медистом» золоте. Минералы элементов платиновой группы представлены самородной Pt без примесей или, возможно, с некоторым количеством $\mathrm{Fe}$, а также соединениями, анализы которых пересчитываются на идеальные формулы $\mathrm{PdPt}$ (по анализам - $\mathrm{Pd}_{1,06-0,92} \mathrm{Pt}_{0,94-1,08}$ ), $\mathrm{Pd}_{3} \mathrm{Ag}$ и $\mathrm{Pd}_{4} \mathrm{Ag}$ (табл. 2).

\section{Обсуждение результатов исследований}

Протолиты скарнов Белогорского месторождения изначально были обогащены не только $\mathrm{Au}, \mathrm{Ag}, \mathrm{Pd}$ и $\mathrm{Pt}$, но и многими другими второстепенными элементами. В виде микровключений залежи содержат минералы Zr, Th, U, V, REE и Y (циркон, бадделеит, торианит, торит, монацит, алланит и др.), Ва и $\mathrm{Sr}$ (барит, санборнит и др.), Sn, W, Mo, Nb и Та (касситерит, станнин, вольфрамит, шеелит, молибденит-повеллит, ильземанит и др.). Встречаются соединения $\mathrm{Tl}$ и $\mathrm{Hg}$ (лафоссаит, киноварь и колорадоит), $\mathrm{Bi}, \mathrm{Te}$ и $\mathrm{Pb}$ (самородный $\mathrm{Bi}$, висмутин, жозеит, хедлейит, $\mathrm{Bi}_{4} \mathrm{Te}$, $\mathrm{Bi}_{5} \mathrm{Te}, \mathrm{Bi}_{6} \mathrm{Te}$, гладит и др.), $\mathrm{Ni}, \mathrm{Co}, \mathrm{As}$ и $\mathrm{Sb}\left(\mathrm{Ni}_{2} \mathrm{As}_{3}\right.$, никелин, герсдорфит, кобальтин, ульманит, арсенопирит, гудмундит, леллингит, бурнонит, стибнит, самородная сурьма), $\mathrm{Zn}, \mathrm{Cu}$ и In (сфалерит, халькопирит, $\mathrm{InPO}_{4}$ и др.). Распространены разнообразные самородные элементы, неупорядоченные твердые растворы металлов и интерметаллические соединения.

Процессы минералообразования в скарновых залежах происходили в условиях постепенного понижения температуры метаморфизма, приводившего к существенному изменению минеральных форм породообразующих и редких элементов с течением времени. Наиболее ранние и высокотемпературные образования основных залежей месторождения - Благодатной, Белогорской и Маргаритовской, представлены массивными гранатовыми и “бурундучными” магнетит-гранатовыми скарнами со следами интенсивного объемного средне-низкотемпературного преобразования. Их главной особенностью было замещение граната магнетитом с образованием в наиболее переработанных участках блоков существенно магнетитового состава [9]. К таким участкам приурочены карбонатные гнезда с крупнокристаллическими флюори- том, родонитом, манганактинолитом и сфалеритом. Их количество и размеры напрямую зависят от степени замещения граната магнетитом. Главной особенностью этого процесса являлось разложение граната, F-содержащих и других ранних минералов и высвобождение $\mathrm{Fe}, \mathrm{Ca}, \mathrm{Si}, \mathrm{Mn}$ и F. Железо почти полностью фиксировались на месте в виде магнетита. Кальций, марганец и фтор испытывали локальные перемещения и в различных минеральных формах отлагались в составе рассекающих весь объем скарнов густой сетки тонких извилистых прожилков и просечек гранаткарбонатного (с флюоритом и родонитом) состава, фиксирующих пути наиболее интенсивного выноса элементов, и в составе карбонатных гнезд.

В массивных гранатовых и “бурундучных" магнетит-гранатовых скарнах встречаются, главным образом, кислородные соединения $\mathrm{Zr}, \mathrm{Th}, \mathrm{U}, \mathrm{V}, \mathrm{Sc}, \mathrm{Nb}$, REE, Y, Ba, Sr, Sn, W, а также арсениды, сульфоарсениды и сульфоантимониды $\mathrm{Ni}$ и Со. Олово и цинк присутствуют, в основном, в виде изоморфной примеси в гранате и клинопироксене, соответственно [9 и др.]. Минералы редких элементов в массивных гранатовых и «бурундучных» магнетит-гранатовых скарнах образуют микровключения в породообразующих минералах без признаков замещения и коррозии (рис. 3). Они встречаются и в более поздних минеральных образованиях, но, очевидно, лишь в качестве реликтовых.

Разнообразные минералы редких элементов характерны и для продуктов низко-, среднетемпературного изменения массивных гранатовых и «бурундучных» магнетит-гранатовых скарнов. Они образуют микровключения в магнетите сливного облика, образовавшегося в результате разложения граната, а также включения и просечки (по плоскостям спайности) в карбонате и флюорите. К этой группе относятся касситерит, сфалерит, галенит, пирит, халькопирит, арсенопирит, гудмундит, аргентит, леллингит, станнин, самородный висмут и висмутовые соединения, сульфосоли, молибденит, повеллит и члены шеелит-повеллитового изоморфного ряда, стибнит, самородная $\mathrm{Sb}$ и многие другие минералы. Для магнетита наиболее характерны микровключения касситерита, образовавшиеся за счет $\mathrm{Sn}$, присутствовавшего в гранате, а для карбоната и флюорита микровключения сфалерита, висмутовых минералов (рис. 4), молибденита и членов шеелит-повеллитового изоморфного ряда.

Минералы $\mathrm{Au}$ и платиноидов встречаются в виде самостоятельных зерен в ранних минералах (гранате, магнетите, апатите и других) (рис. 5, а, б), а также в продуктах средне-, низкотемпературного преобразования залежей (карбонате, новообразованном магнетите, флюорите и других) (рис. 5, в). Самородное $\mathrm{Au}$ без примесей и $\mathrm{Au}-\mathrm{Ag}$ твердый раствор наиболее часто образуют включения в ранних минералах (гранате, магнетите, апатите и др.) и в продуктах средненизкотемпературного преобразования скарнов (карбонате, флюорите, амфиболе и других минералах). В 

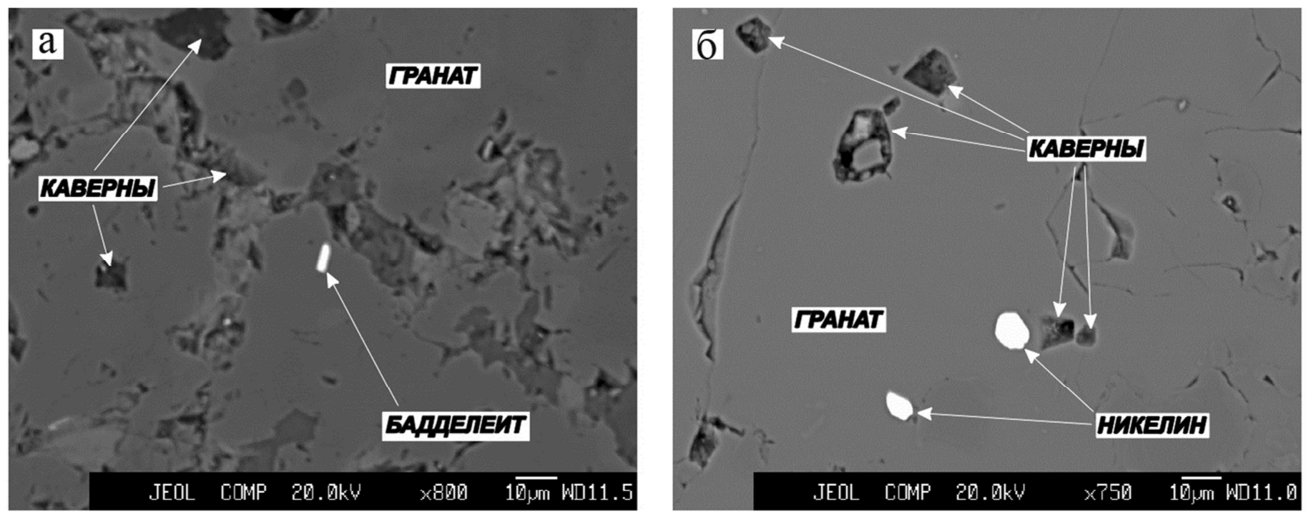

Puc. 3. Включения бадделеита (а) и никелина (б) в гранате. Вид в отраженных электронах. $a$ - Белогорская залежь, обр. Б-79-14; 6 - Скальная залежь, обр. Ш-86-146 (2).
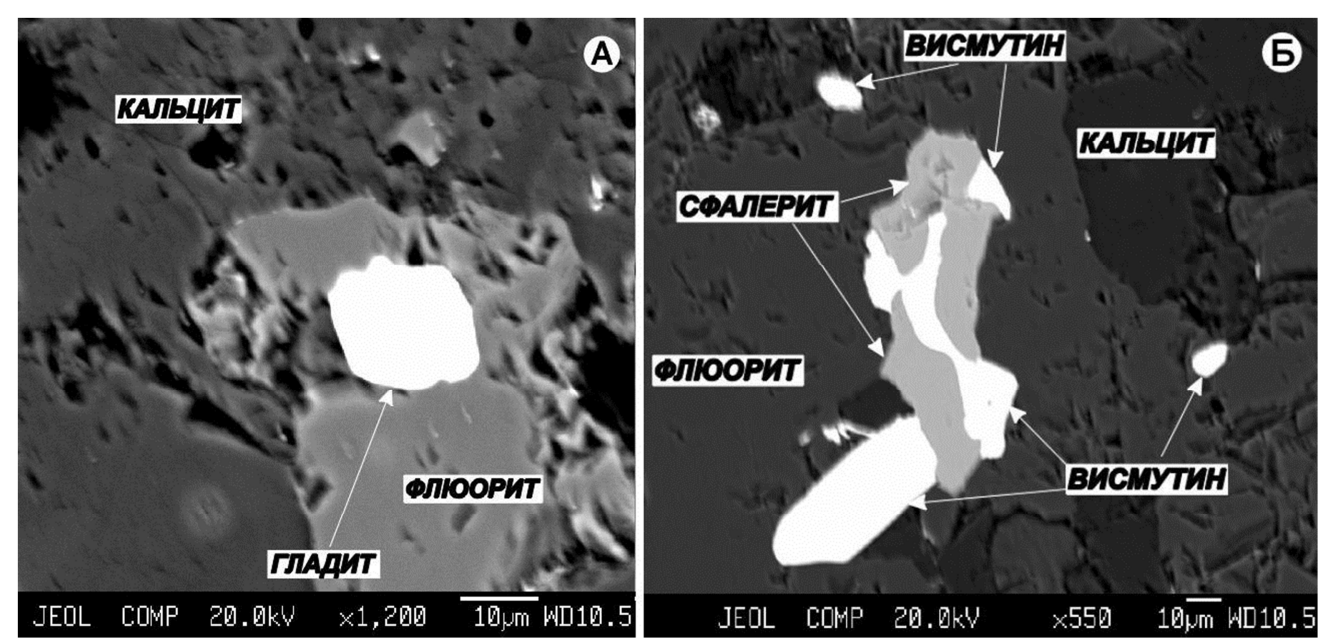

Puc. 4. Кристалл гладита (a) и срастание висмутина и сфалерита в флюорите (б). Вид в отраженных электронах. Обр. Б-79-74. Благодатная залежь.
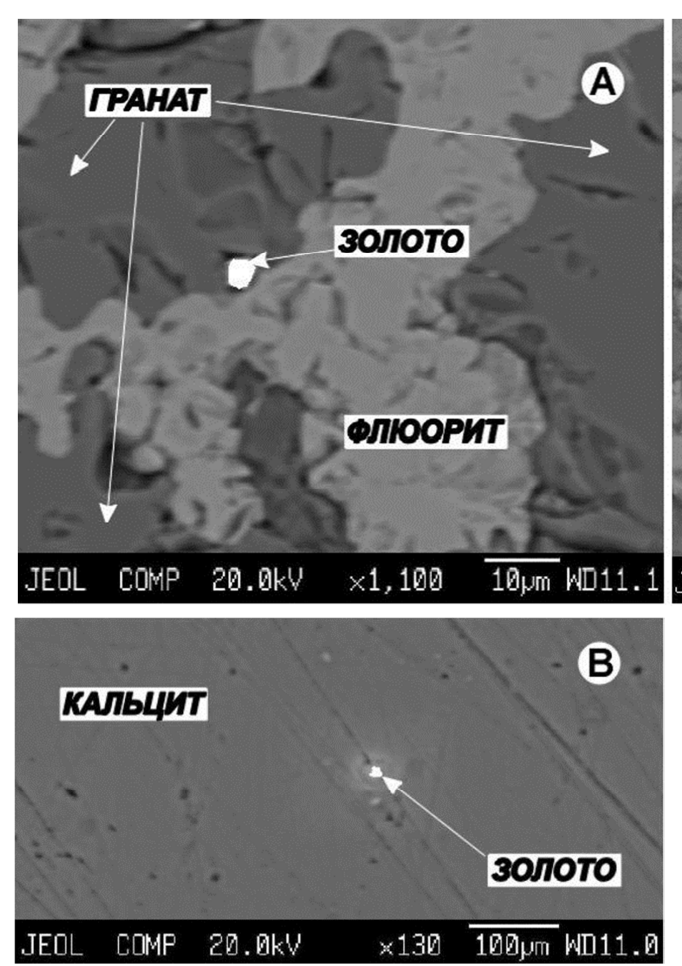

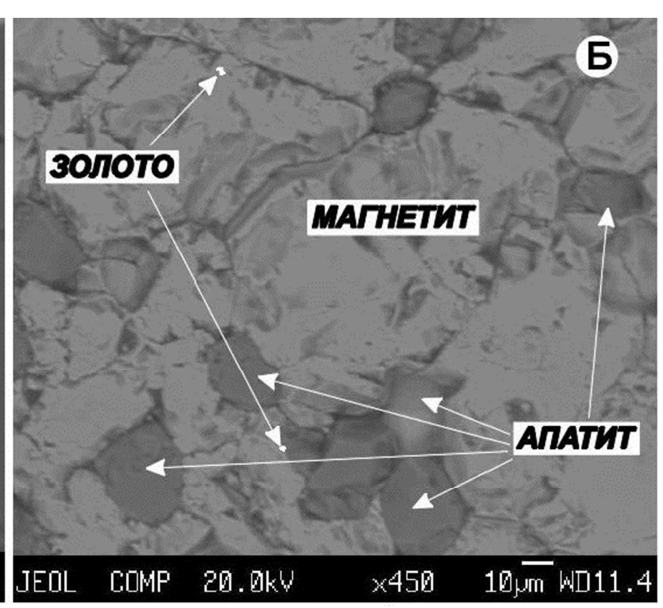

Рис. 5. Включения самородного золота в гранате (a) (обр. Б-79-25), апатите, магнетите (б) (обр. Б-79) и кальците (в) (обр. Б-7959) Благодатной залежи Белогорского месторождения. "Гало" вокруг зерна самородного золота на рис. 5 в - следствие воздействия электронного пучка на окружающий кальцит. Вид в отраженных электронах. 
последнем случае самородное золото иногда образует срастания с висмутовыми минералами или сфалеритом или встречается в ассоциации со сфалеритом и леллингитом. Основными концентраторами Ag в Белогорском месторождении являются висмутовые минералы, галенит, блеклая руда и другие сульфосоли. Все эти минералы характерны для продуктов преобразования ранних ассоциаций. Они слагают бесформенные выделения и хорошо образованные кристаллы в карбонате и флюорите или просечки по плоскостям спайности этих минералов.

Необычные разновидности самородных золота и платины (с $\mathrm{Cu}, \mathrm{Co}, \mathrm{Ni}, \mathrm{Zn}$ и $\mathrm{Pb}$ ) и «медистое золото» наиболее часто присутствуют в порах и микротрещинах с органическим веществом в ранних минералах, однако эта закономерность не является строгой, так как включения $\mathrm{Cu}$ - и $\mathrm{Zn}$-содержащего $\mathrm{Au}$ отмечались и в карбонате. Они встречаются, главным образом, вместе с предельно восстановленными формами других металлов (самородными элементами и интерметаллическими соединениями), для кристаллизации которых требуются высоко- и ультравосстановительные условия.

«Медистое золото», природные латуни и бронзы, минералы $\mathrm{Au}, \mathrm{Ag}, \mathrm{Pt}$ и $\mathrm{Pd}$, а также широкий спектр самородных элементов и интерметаллических соединений, в том числе фосфиды, силициды и хромиды, являются специфической особенностью Таухинского и Самаркинского террейнов Сихотэ-Алиня. Они распространены в углеродистых триасовых силицитах
[13] и в залегающих непосредственно над последними (в стратиграфической колонке) метаморфизованных триасовых металлоносных осадках, прилегавших к островам акваторий - марганцевосиликатных породах и силикатно-магнетитовых рудах [14]. Подобные минералы встречаются и в ассоциированных с углеродистыми силицитами и метаморфизованными триасовыми металлоносными осадками скарнах с полиметаллическими и боросиликатными рудами в Дальнегорском рудном районе [2]. Во всех перечисленных породах эти минералы образуют, главным образом, мельчайшие (диаметром доли мкм - первые десятки мкм) зерна. Наиболее высокие концентрации Au, Pt и $\mathrm{Pd}$ характерны для метаморфизованных триасовых металлоносных осадков и, в меньшей мере, скарнов. Положение точек на диаграмме (рис. 6) свидетельствует в пользу присутствия в залежах Белогорского месторождения неупорядоченных $\mathrm{Au}-\mathrm{Cu}$ (примерно, в области составов «Au- $\mathrm{Au}_{2} \mathrm{Cu}$ ) и $\mathrm{Au}-\mathrm{Ag}$ твердых растворов, а также интерметаллических соединений, близких по составу к купроауриду и аурикуприду. Для сравнения на этот рисунок вынесены точки минералов системы «Au-Cu-Ag», ранее обнаруженных в триасовых метаморфизованных металлоносных осадках Ольгинского и Дальнереченского рудных районов, а также в Дальнегорском боросиликатном и полиметаллических месторождениях Дальнегорской группы. Минералы благородных металлов, самородные элементы и интерметаллические соединения в скарнах и метаморфизованных металлоносных осадках

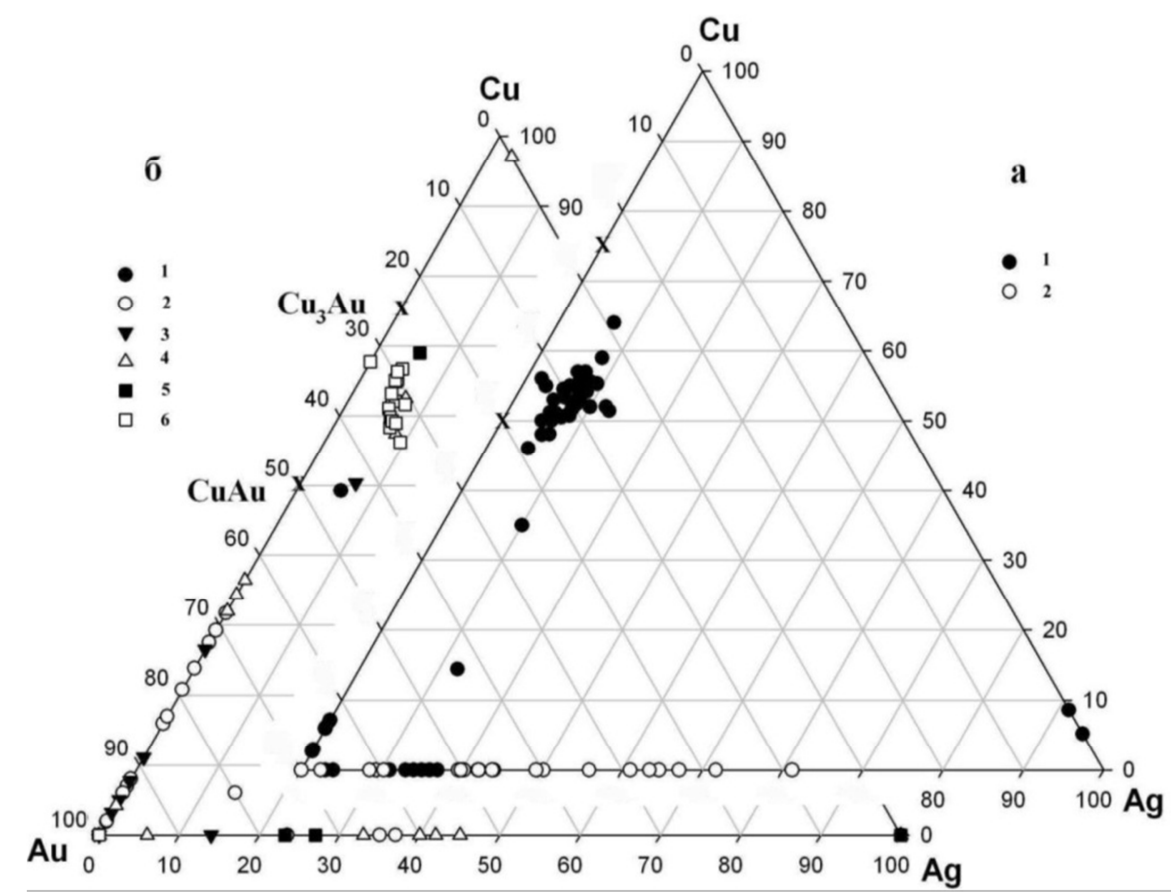

Pис. 6. Особенности состава минералов системы “Au-Cu-Ag” в триасовых метаморфизованных металлоносных осадках Сихотэ-Алиня (марганцевосиликатных породах, силикатно-магнетитовых рудах и яшмах) (а) и скарновых месторождениях Ольгинского и Дальнегорского рудных районов Приморья (б). а: 1 - точки состава мелких (до 10 мкм) зерен, приуроченных к порам и микротрещинам с органикой; 2 - точки состава относительно крупных зерен, выделенных растворением проб в плавиковой кислоте. б: 1-4 - Белогорская (1), Благодатная (2), Маргаритовская (3) и Скальная (4) залежи Белогорского месторождения, 5 Дальнегорское боросиликатное месторождение, 6 - Садовое месторождение. Крестиками показано положение теоретических составов купроаурида и аурикуприда. 
встречаются в ранних минеральных ассоциациях, однако, наиболее часто присутствуют в минерализованных микротрещинах с органическим веществом. Их присутствие объясняется влиянием органического вещества «глинисто-кремнистой толщи» $[15,16]$. Оно связано с удалением из углеродистых пород при нагревании наиболее летучих компонентов, в первую очередь, плохо связанной воды и углеводородов, и возникновению, таким образом, некоторого объема флюида с высоко- и ультравосстановительными способностями, мигрировавшего по трещинам в другие породы. Следы этого процесса в виде систем маломощных минерализованных трещин, содержащих органическое вещество, минералы $\mathrm{Au}, \mathrm{Ag}, \mathrm{Pt}$ и $\mathrm{Pd}$, разнообразные самородные элементы и интерметаллические соединения, присутствуют и в осадочных породах, ассоциированных с триасовыми углеродистыми силицитами [15].

\section{Заключение}

Таким образом, залежи Белогорского месторождения обогащены $\mathrm{Au}, \mathrm{Ag}, \mathrm{Pt}$ и $\mathrm{Pd}$ и содержат минералы благородных металлов. Золото, серебро, платина и палладий присутствуют в виде неупорядоченных твердых растворов и разнообразных интерметаллических соединений. Наряду с самородными золотом и платиной без примесей и $\mathrm{Au}-\mathrm{Ag}$ твердым раствором распространены необычные (с $\mathrm{Cu}, \mathrm{Co}, \mathrm{Ni}, \mathrm{Zn}$ и $\mathrm{Pb}$ ) разновидности и довольно редкое в природе «медистое золото».

Благороднометальная минерализация в скарновых залежах Белогорского месторождения имеет двойственную природу. Она образовались в процессе метаморфизма за счет вещества протолитов (накапливавшихся в лагунах островов продуктов размыва латеритной коры выветривания габброидов), а также за счет благородных металлов триасовых углеродистых силицитов, мигрировавших по трещинам в другие породы в составе флюида с высоко- и ультравосстановительными способностями. Обогащение благородными и другими металлами протолитов скарнов, триасовых метаморфизованных металлоносных осадков и триасовых углеродистых силицитов обусловлено, вероятно, их сорбированием гидроксидами Мn и $\mathrm{Fe}$, а также органическим веществом в процессе экзогенного выветривания габброидов.

\section{ЛИТЕРАТУРА}

1. Казаченко, В. Т. Геохимические и изотопные «метки» древних габброидов в триасовых метаморфизованных металлоносных осадках, скарнах и рудах скарновых месторождений Сихотэ-Алиня / В. Т. Казаченко, Е. В. Перевозникова, С. Н. Лаврик // Вестник КНЦ РАН. - 2016. - №4 (27). - C. $16-36$.

ФБУН Дальневосточный геологический институт Дальневосточного отделения РАН, г. Владивосток Перевозникова Елена Валериевна, кандидат геологоминералогических наук, старший научный сотрудник E-mail: elenavalper@yandex.ru; Тел.: +7 (423) 2317834 Казаченко Валентин Тимофеевич, доктор геологоминералогических наук, главный научный сотрудник E-mail:vkazachenko@mail.ru ; Tел.: +7 (423) 2317834
2. Казаченко, В. Т. Акцессорная минерализация в скарнах Дальнегорского рудного района (Сихотэ-Алинь) / В. Т. Казаченко, Е. В. Перевозникова, Г. А. Нарнов // ЗРМО. - 2012. - №.4. - C. 74-96.

3. Лобанова, Г. М. Условия нахождения куспидиновых и монтичеллитовых скарнов в месторождениях Южного Приморья / Г. М. Лобанова // ЗВМО. - 1960. - Ч. 89.- Вып. 5. - C. 523-541.

4. Геология свинцово-цинковых месторождений Приморья / Е. А. Радкевич [и др.] // Труды ИГЕМ АН СССР. - 1960. Вып. 34. - Т. 1.-328 c.

5. Гуляева, Т. Я. Оловосодержащий андрадит Белогорского месторождения (Приморье) / Т. Я. Гуляева // Тихоокеанская геология. - 1982. - № 5. - С. 110-113.

6. Гуляева, Т. Я. Микронеоднородности редких разновидностей магнетита и их генетическое значение / Т. Я. Гуляева, С. А. Щека / Минералы - индикаторы петрогенезиса. Владивосток. 1980. - С. 62-68.

7. Гуляева, Т. Я. О редкой $\mathrm{Zn-Mg-марганцевой} \mathrm{разновид-}$ ности магнетита / Т. Я. Гуляева, С. А. Щека // ДАН СССР. 1982. - T. 267. - № 6. - C. 1448-1453.

8. Manganous amphiboles and layered silicates from a polymetallic deposit in Primorye, U.S.S.R. / V. T. Kazachenko [et. al.] // Jb. Miner. Abh. - 1981.- Bd. 140. - H. 2. - P. 165-183.

9. Казаченко, В. Т. Минералогия и генезис Белогорского скарново-магнетитового месторождения (Приморье) / В. Т. Казаченко, Е. В. Перевозникова, С. Н. Лаврик // Тихоокеанская геология. - Т. 30. - № 6. - 2011. - С. 67-83.

10. Покровский, П. В. К минералогии самородного золота месторождения Золотая Гора / П. В. Покровский, В. В. Мурзин, Р. О. Берзон // Зап. ВМО. - 1979. - Ч. 108. - № 3. - С. 317-326.

11. Knight, J. B. Phase relations in the system $\mathrm{Au}-\mathrm{Cu}-\mathrm{Ag}$ at low temperatures, based on natural assemblages / J. B. Knight, C. H. B. Leitch // Canad. Mineral. - 2001. - Vol. 39. - P. 889-905.

12. Лотина, А. А. Золото-висмут-теллуровая минерализация в коренных источниках и россыпях месторождения Болотистого (Хабаровский край) : автореф. дис. геол.-мин.наук : 25.00.11/ Лотина Анна Александровна ; Владивосток, 2011. - 26 с.

13. Волохин, Ю. Г. Минералы в углеродистых силицитах триаса Сихотэ-Алиня / Ю. Г. Волохин, А. А. Карабцов // Литология и полезные ископаемые. - 2016. - №5. - С. 465-484.

14. Перевозникова, E. B. Марганцевосиликатные породы Южного Сихотэ- Алиня: минералогия и генезис : дис. канд. геол.-мин.наук : 25.00.11 / Перевозникова Елена Валериевна ; Владивосток, 2010. - 192 с.

15. Казаченко, В. T. Au-Ag-Pd-Pt минерализация в осадочных породах, ассоциирующих с триасовыми углеродистыми силицитами Сихотэ-Алиня / В. Т. Казаченко, Е. В. Перевозникова // Литосфера. - 2018. - Т. 18. - № 6. - С. 892-913.

16. Казаченко, В. T. Особенности процессов накопления и метаморфизма триасовых металлоносных осадков в Таухинском и Самаркинском террейнах Сихотэ-Алиня (по результатам изучения геохимии и минералогии $\mathrm{Th}, \mathrm{U}$ и REE) / В. T. Казаченко, Е. В. Перевозникова // Вестник Воронеж. гос. ун-та. Сер.: Геология. - 2018. - № 2. - С. 72-83.

\section{Far East Geological Institute (FEGI FEB RAS)}

Perevoznikova E.V., Candidate of Geological and Mineralogical Sciences, Senior Researcher

E-mail: elenavalper@yandex.ru; Tel.: +7 (423) 2317834

Kazachenko V. T., Doctor of Geological and Mineralogical

Sciences, Chief Researcher

E-mail:vkazachenko@mail.ru

Tel.: +7 (423) 2317834 